\title{
Side-chain opening of steroidal sapogenins to form 22-oxocholestanic skeletons. An approach to analogues of the aglycone of the potent anticancer agent $\mathrm{OSW}-1$
}

\author{
María A. Fernández-Herrera, Jesús Sandoval-Ramírez, * Socorro Meza-Reyes, and Sara Montiel-Smith
}

Facultad de Ciencias Químicas, Benemérita Universidad Autónoma de Puebla. Ciudad Universitaria, San Manuel, 72570 Puebla, Pue., México. E-mail: jsandova@siu.buap.mx

Received June 5, 2009; accepted August 31, 2009

\begin{abstract}
The side-chain opening of $25 R$ and $25 S$ steroidal sapogenins to form 22-oxocholestanic skeletons is described. The transformation was produced under mild conditions providing high yields $(70-87 \%)$, in a one pot procedure (some acetylated starting material is recovered). This methodology yields 17-deoxy-26-oxy analogues of the aglycone of the potent anticancer agent OSW-1. All products were fully characterized by 1D and 2D NMR; the most representative displacements are briefly discussed.
\end{abstract}

Keywords: steroidal sapogenins, acetolysis, aglycone, OSW-1.

\section{Introduction}

Steroidal sapogenins are natural products obtained from saponins, a group of glycosides widely distributed in plants [1]. In nature, most sapogenins have the $22 R$ configuration, and with regard to $\mathrm{C}-25$ there are two kinds of sapogenins: $25 R$ (the methyl group in C-25 is equatorial oriented), as in diosgenin (1) and hecogenin (2); or $25 S$ (the methyl group in C-25 is axial oriented), as in sarsasapogenin (3, Figure 1). It is very important to highlight the difference of absolute configuration at this center because in many side-chain transformations, products and yields may vary; depending on such configuration.

Sapogenins are all-important natural compounds because of their use in the preparation of some steroidal biologically active products. In the $40 \mathrm{~s}$, sapogenins achieved great economical importance because of their transformation into pregnane derivatives; thus, diosgenin (1) and sarsasapogenin (3) were readily transformed into progesterone [2]; hecogenin (2) was transformed into cortisone and betamethasone [3]. More recently, the steroidal cholestanic saponin OSW-1 (4, Figure 2) and its family analogues ( $\mathbf{5}$ to $\mathbf{8}$ ) were isolated from the bulbs of Ornithogalum saundersiae by Sashida and coworkers [4].

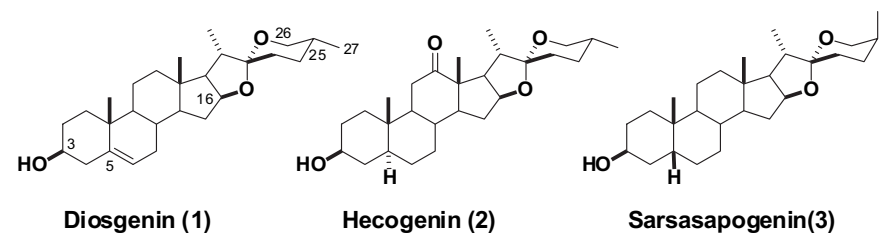

Fig. 1. Structures of natural steroidal sapogenins.
Resumen. Se reporta la apertura de la cadena lateral de sapogeninas esteroidales $25 R$ y $25 S$ para obtener estructuras 22-oxocolestánicas. La transformación fue llevada a cabo bajo condiciones de reacción suaves y con altos rendimientos (70-87\%), en un solo paso (se recupera materia prima acetilada). Con esta metodología se obtienen, en un solo paso, análogos 17-desoxi-26-oxigenados de la aglicona del potente anticancerígeno OSW-1. Todos los productos fueron caracterizados por RMN de una y dos dimensiones y los desplazamientos más representativos se discuten brevemente.

Palabras clave: sapogeninas esteroidales, acetólisis, aglicona, OSW-1.

Compound $\mathbf{4}$ exhibited extraordinary cytostatic activity against a great number of human malignant tumor cells. The antiproliferative activity of $\mathbf{4}$ is around 10-100 times more potent than some anticancer agents currently in clinical use, such as taxol, cis-platin, adriamycin and mitomycin C [5]. The total synthesis of OSW-1 has been carried out by some authors but yields are low due to the long synthesis of the aglycone [6].

The spiroketal function is derived from the cholesterol side-chain by a series of oxygenation reactions, hydroxylating $\mathrm{C}-16$ and one of the terminal methyls, and then producing a ketone function at C-22 (Scheme 1). This proposed intermediate is transformed into the hemiketal and then the spiroketal. The chirality at C-22 is fixed by the stereospecificity in the formation of the ketal while the different stereochemistry at C-25 are dictated by whether C-26 or C-27 is hydroxylated in the earlier step [7]. Theoretically, the spiroketal side-chain opening under the appropriate conditions, should provide the

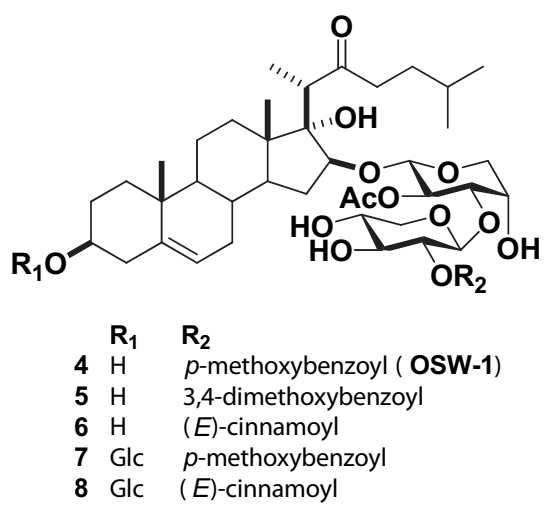

Fig. 2. Structure of OSW-1 and its family of cholestane glycosides. 
desired protosapogenin 9 (Scheme 1) which represents the ideal pathway for the formation of analogues of the OSW-1 aglycone. However such a system is very reactive under acidic and neutral conditions, displacing instantaneously the equilibrium to the spiroketal moiety. Until now this kind of opening has been a hard challenge.
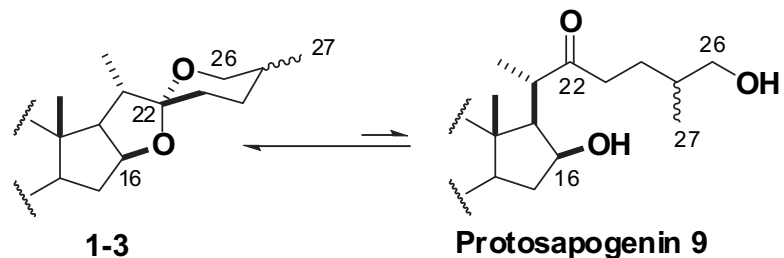

Scheme 1. Equilibrium between the spiroketal side-chain and the corresponding protosapogenin skeleton.

An initial effort to obtain a protosapogenin side-chain attempting to trap the carbonyl group at C-22, was reported by Djerassi [8]. The treatment of diosgenin acetate 1a with $\mathrm{BF}_{3} \cdot \mathrm{OEt}_{2}$ in the presence of ethanedithiol provided the 26thioacetal 11 instead of the 22-thioketal 10. The intramolecular redox reaction occurred at room temperature in $2 \mathrm{~h}$ (Scheme 2); later, similar results were reported by Tian [9].

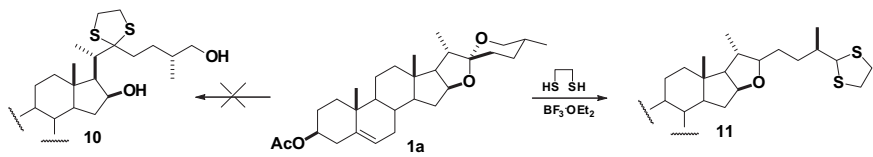

Scheme 2. Attempted sapogenin side-chain opening in order to obtain a protosapogenin.

\section{Results and Discussion}

Following recent work on new transformations of the spiroketal moiety of sapogenins to obtain interesting steroidal structures desirable for partial synthesis [10], an attempt was made to trap the protosapogenin side-chains of $\mathbf{1 - 3}$, protecting in situ their diol functionalities (at C-16 and C-26). In this way, cyclization of the cholestanic protosapogenin 9 towards the spirostane skeleton would be avoided. Our studies established the best way to open the $\mathrm{E}$ ring to afford 22,26-epoxycholestene frameworks (12-14, Scheme 3$)$ by means of $\mathrm{Ac}_{2} \mathrm{O} /$ Lewis acid at room temperature $[10 \mathrm{a}, \mathrm{b}]$. In this report, a mild opening process of the spiroketal moiety towards the corresponding protected protosapogenin is described. When sapogenins 1-3 were treated by means of $\mathrm{Ac}_{2} \mathrm{O}, \mathrm{BF}_{3} \cdot \mathrm{OEt}_{2}$, in a range of temperatures between 0 and $-5{ }^{\circ} \mathrm{C}$, the resulting products were the 22-oxocholestanic-26-acetylated skeletons 15-17, yielded in $70-87 \%$ (Table 1). In the range of -5 to $0{ }^{\circ} \mathrm{C}$ the 22 -oxocholestanic-26-acetylated framework was the main product; however,
Table 1. Influence of temperature in the yield of 15-17.

\begin{tabular}{cccccccc}
\hline & \multicolumn{6}{c}{ Yield (\%) of 15-17 after chromatography } \\
\cline { 2 - 8 } Compound & $-15^{\circ} \mathrm{C}$ & $-10{ }^{\circ} \mathrm{C}$ & $-5{ }^{\circ} \mathrm{C}$ & $0{ }^{\circ} \mathrm{C}$ & $5{ }^{\circ} \mathrm{C}$ & $10{ }^{\circ} \mathrm{C}$ & $15^{\circ} \mathrm{C}$ \\
\hline $\mathbf{1 5}$ & 3 & 20 & 80 & 85 & 72 & 12 & 0 \\
$\mathbf{1 6}$ & 2 & 21 & 83 & 87 & 75 & 10 & 0 \\
$\mathbf{1 7}$ & 2 & 19 & 61 & 70 & 50 & 8 & 0 \\
\hline
\end{tabular}

some starting material was recovered. When the temperature was increased, epoxicholestenes and furostenes were the main products $[10 \mathrm{a}, \mathrm{b}]$.

Under aforementioned conditions, a suitable reaction mechanism is detailed in order to explain the reactivity of the side-chain of sapogenins, (Scheme 3). The oxophilic $\mathrm{BF}_{3} \cdot \mathrm{OEt}_{2}$ selectively catalyzes the opening of ring $\mathrm{E}$ and the formation of oxonium ion $\boldsymbol{i}$; simultaneously, the hydroxyl group at $\mathrm{C}-16$ is protected. The intermediate oxonium ion $\boldsymbol{i}$ enables the nucleophilic attack by the acetate anion at C-26 to afford compounds 15-17. At $0{ }^{\circ} \mathrm{C}$ we obtained the best yield for compounds 15-17. It is important to notice that the yield of $\mathbf{1 7}$ was lower, because of the steric hindrance of the $\mathrm{C}-27$ axial methyl group.

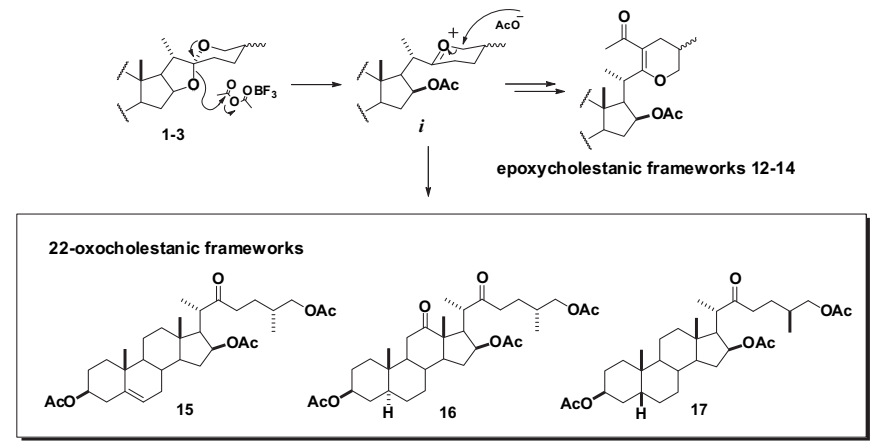

Scheme 3. Plausible mechanism for the formation of 22-oxocholestanic-26-acetylated side-chains.

The transformation of the ketal group at $\mathrm{C}-22$ into the corresponding C-22 ketone produced the expected downfield shifts for both $\mathrm{H}-23$ methylenic and $\mathrm{H}-20$ methynic protons. The latter and the signal pattern for $\mathrm{H}-26$ protons (close $\delta$ values) indicate that rings $\mathrm{E}$ and $\mathrm{F}$ are opened. Table 2 shows the main ${ }^{1} \mathrm{H}$ and ${ }^{13} \mathrm{C}$ chemical shifts observed for compounds 1517. The acetate methyl groups at positions 3,16 and 26 were characterized by HMBC experiment, the carbonyl groups of such acetates are long distance-coupled with their corresponding 3,16 and 26 protons; this evidence allowed the full assignment of such signals.

The spectra of compounds 15-17 are displayed in Figure 3 ; around the region of 5.40 to $2.20 \mathrm{ppm}$. Towards $5.00 \mathrm{ppm}$ $\mathrm{H}-16 \beta$ signals appear for all compounds. The signals for $\mathrm{H}-3$ in spectra of $\mathbf{1 5}$ and $\mathbf{1 6}$ are wider than that of $\mathbf{1 7}$ because of its $5 \beta$ stereochemistry, with a typical $\mathrm{W}^{1} / 2$ of $8 \mathrm{~Hz}$. Diastereotopic H-26 signals have the characteristic chemical shifts of an opened cholestanic side-chain, and differ considerably from 
Table 2. Selected ${ }^{1} \mathrm{H}$ and ${ }^{13} \mathrm{C}$ NMR data for compounds 15-17 ( $\delta$ in ppm, $\mathrm{CDCl}_{3}$ ).

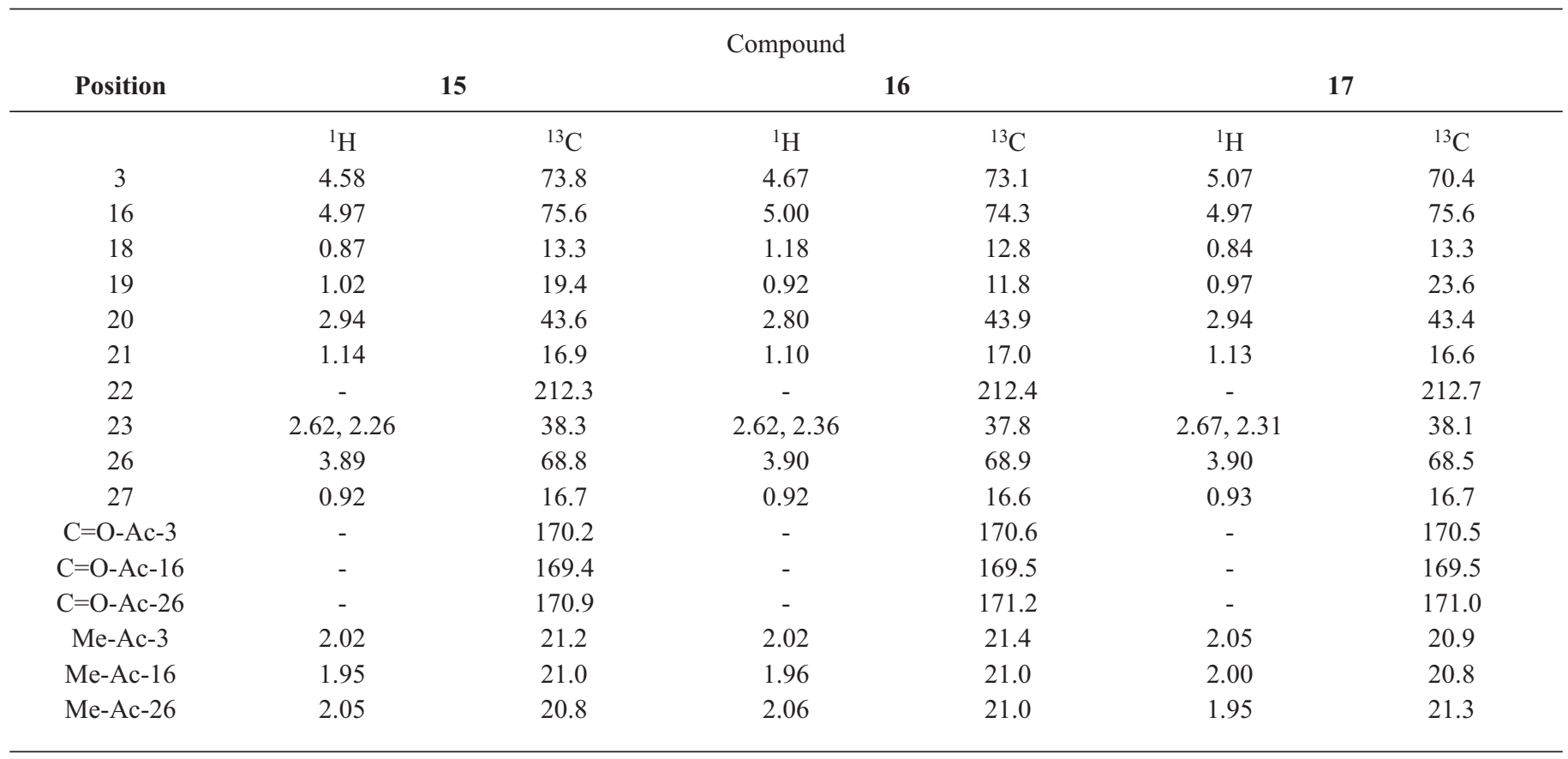

those of the starting materials. $\mathrm{H}-26$ protons are displayed as an $\mathrm{ABX}$ system.

The full assignments of the ${ }^{13} \mathrm{C}$ NMR signals of the 22oxocholestanic products were obtained with the aid of DEPT, HSQC and HMBC experiments. The resonance signals for C-23 and C-20 in all cases were shifted downfield because of the effect of the new carbonyl group at $\mathrm{C}-22$. As predicted in the hypothesis of the reaction mechanism, the $\mathrm{C}-16 \beta$ and $\mathrm{C}-26$ hydroxyl groups were protected in situ. The ${ }^{13} \mathrm{C}$ data showed the $\delta$ for $\mathrm{C}-16$ and $\mathrm{C}-26$ as a typical acetate protected alcohol and the corresponding methyl and carbonyl groups of the acetates were fully assigned. Data are summarized in Table 3.

15
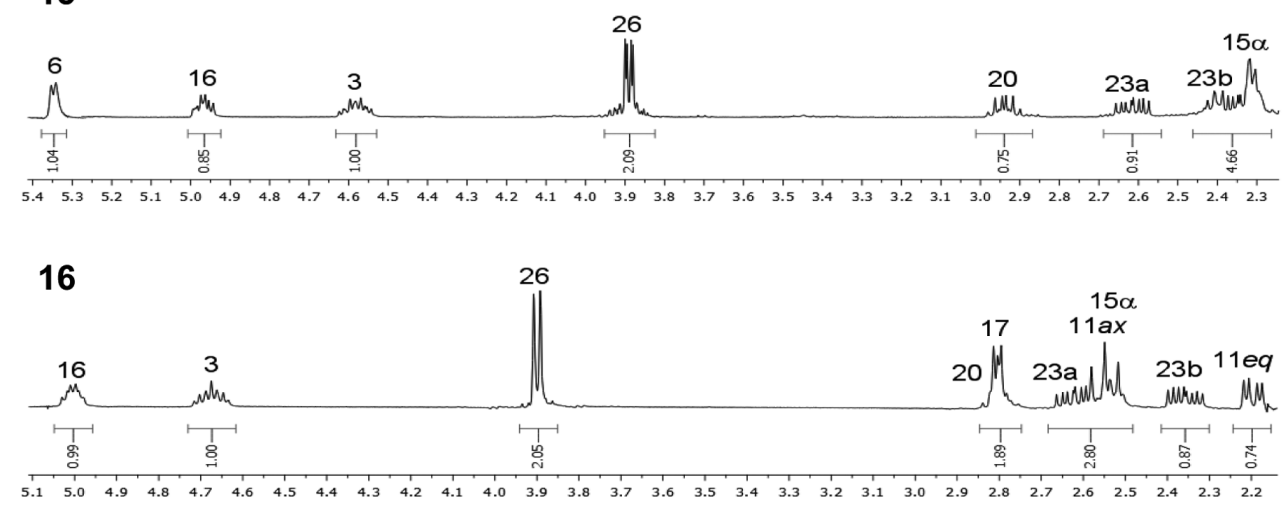

17

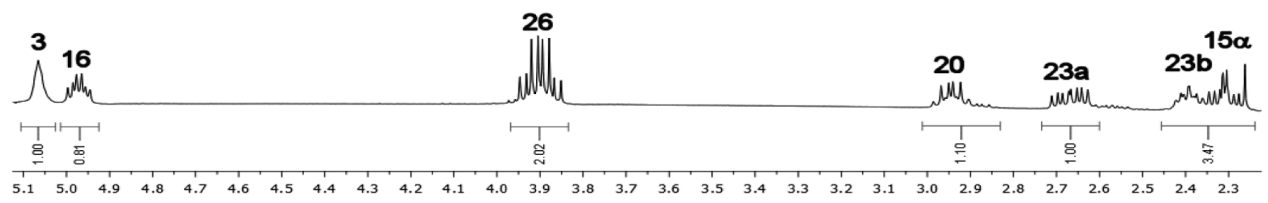

Fig. 3. Partial ${ }^{1} \mathrm{H}$ NMR spectra of compounds 15-17. 


\section{Conclusions}

In summary, a novel and efficient opening of the spiroketal moiety of diosgenin, hecogenin and sarsasapogenin is reported. We determined that the temperature is one of the most important parameters in order to obtain selectively such cholestanic frameworks. At low temperatures $\left(-5\right.$ to $\left.0{ }^{\circ} \mathrm{C}\right)$, 17-deoxy-26-oxy analogues of the aglycone of the potent anticancer agent OSW-1 were obtained in high yields under mild reaction conditions.

\section{Experimental Section}

General procedure for the formation of 15-17. Sapogenin 1-3 (7 mmol) was dissolved in $20 \mathrm{~mL}$ of $\mathrm{CH}_{2} \mathrm{Cl}_{2}$ and $10 \mathrm{~mL}$ of $\mathrm{Ac}_{2} \mathrm{O}(106 \mathrm{mmol})$ and cooled down to $0{ }^{\circ} \mathrm{C}$; then, $6 \mathrm{~mL}$ of $\mathrm{BF}_{3} \cdot \mathrm{OEt}_{2} ;(48 \mathrm{mmol})$ were added dropwise. The mixture was stirred for $15 \mathrm{~min}$ and the resulting syrup was added to $50 \mathrm{~mL}$ of iced water. The organic phase was washed with saturated solution of $\mathrm{NaHCO}_{3}(4 \times 50 \mathrm{~mL})$ and dried over $\mathrm{Na}_{2} \mathrm{SO}_{4}$, then concentrated under reduced pressure. The crude was purified by chromatography using silica gel, and a mixture of hexanes/ ethyl acetate (85:15) as eluent, to afford compounds 15-17 in $70-87 \%$ yield.

Analytical data for compound 15. Colorless solid; mp 146-148 ${ }^{\circ} \mathrm{C} ;[\alpha]_{\mathrm{D}}=+2.1^{\circ}\left(c 1.1, \mathrm{CHCl}_{3}\right) .{ }^{1} \mathrm{H}$ NMR $\left(400 \mathrm{MHz}, \mathrm{CDCl}_{3}\right.$

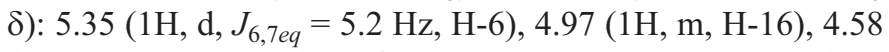
$(1 \mathrm{H}, \mathrm{m}, \mathrm{H}-3), 3.89\left(2 \mathrm{H}, \mathrm{d}, J_{26,25}=6.4 \mathrm{~Hz}, \mathrm{H}-26\right), 2.94(1 \mathrm{H}$, dq, $\left.J_{20,21}=6.8 \mathrm{~Hz}, J_{20,17}=4.0 \mathrm{~Hz}, \mathrm{H}-20\right), 2.62(1 \mathrm{H}, \mathrm{m}, \mathrm{H}-$ 23a), $2.40(1 \mathrm{H}, \mathrm{m}, \mathrm{H}-15 \mathrm{\alpha}), 2.32\left(1 \mathrm{H}, \mathrm{s}_{\mathrm{br}}, \mathrm{H}-4 e q\right), 1.95(3 \mathrm{H}, \mathrm{s}$, $\left.\mathrm{CH}_{3} \mathrm{CO}_{2}-16\right), 2.02\left(3 \mathrm{H}, \mathrm{s}, \mathrm{CH}_{3} \mathrm{CO}_{2}-3\right), 2.05\left(3 \mathrm{H}, \mathrm{s}, \mathrm{CH}_{3} \mathrm{CO}_{2^{-}}\right.$ 26), $1.14\left(3 \mathrm{H}, \mathrm{d}, J_{21,20}=6.8 \mathrm{~Hz}, \mathrm{CH}_{3}-21\right), 1.02\left(3 \mathrm{H}, \mathrm{s}, \mathrm{CH}_{3}-\right.$ 19), $0.92\left(3 \mathrm{H}, \mathrm{d}, J_{27,25}=6.8 \mathrm{~Hz}, \mathrm{CH}_{3}-27\right), 0.87\left(3 \mathrm{H}, \mathrm{s}, \mathrm{CH}_{3^{-}}\right.$ 18). ${ }^{13} \mathrm{C}$ NMR (100 MHz, $\left.\mathrm{CDCl}_{3} \delta\right): 36.9$ (C-1), $27.8(\mathrm{C}-2)$, 73.8 (C-3), 38.1 (C-4), 139.4 (C-5), 122.1 (C-6), 31.6 (C-7), 31.3 (C-8), 49.8 (C-9), 36.6 (C-10), 20.8 (C-11), 39.6 (C-12), 41.9 (C-13), 53.9 (C-14), 34.9 (C-15), 75.6 (C-16), 55.0 (C17), 13.3 (C-18), 19.4 (C-19), 43.6 (C-20), 16.9 (C-21), 212.3 (C-22), 38.3 (C-23), 26.8 (C-24), 32.2 (C-25), 68.8 (C-26), 16.7 (C-27), $169.4\left(\mathrm{CH}_{3} \mathrm{CO}_{2}-16\right), 170.2\left(\mathrm{CH}_{3} \mathrm{CO}_{2}-3\right), 170.9$ $\left(\mathrm{CH}_{3} \mathrm{CO}_{2}-26\right), 21.0\left(\mathrm{CH}_{3} \mathrm{CO}_{2}-16\right), 21.2\left(\mathrm{CH}_{3} \mathrm{CO}_{2}-3\right), 20.8$ $\left(\mathrm{CH}_{3} \mathrm{CO}_{2}-26\right)$. IR $\left(\mathrm{cm}^{-1}\right): 2936(\mathrm{CH}), 1728(\mathrm{C}=\mathrm{O}$, acetate $)$, $1708\left(\mathrm{C}=\mathrm{O}\right.$, ketone), $1597(\mathrm{C}=\mathrm{C})$. HRMS for $\mathrm{C}_{33} \mathrm{H}_{50} \mathrm{O}_{7}$ Calcd: 558.3557. Found: 558.3551.

Analytical data for compound 16. Colorless solid; mp 195$197{ }^{\circ} \mathrm{C} ;[\alpha]_{\mathrm{D}}=+78.2^{\circ}\left(c 1.0, \mathrm{CHCl}_{3}\right) .{ }^{1} \mathrm{H} \mathrm{NMR}(400 \mathrm{MHz}$, $\left.\mathrm{CDCl}_{3} \delta\right): 5.00(1 \mathrm{H}, \mathrm{m}, \mathrm{H}-16), 4.67(1 \mathrm{H}, \mathrm{m}, \mathrm{H}-3), 3.90(2 \mathrm{H}$, d, $\left.J_{26,25}=6.0 \mathrm{~Hz}, \mathrm{H}-26\right), 2.80(1 \mathrm{H}, \mathrm{m}, \mathrm{H}-20), 2.80(1 \mathrm{H}, \mathrm{m}$, $\mathrm{H}-17), 2.62(1 \mathrm{H}, \mathrm{m}, 23 \mathrm{a}), 2.55\left(1 \mathrm{H}, \mathrm{dd}, J_{11 a x, 9}=J_{11 a x, 11 e q}\right.$ $=12.6 \mathrm{~Hz}, \mathrm{H}-11 \mathrm{ax}), 2.54(1 \mathrm{H}, \mathrm{m}, \mathrm{H}-15 \alpha), 2.36(1 \mathrm{H}, \mathrm{m}$, $\mathrm{H}-23 \mathrm{~b}), 2.20\left(1 \mathrm{H}, \mathrm{dd}, J_{11 e q, 9}=4.8 \mathrm{~Hz}, J_{11 e q, 11 a x}=12.6 \mathrm{~Hz}\right.$, $\mathrm{H}-11$ eq), $2.06\left(3 \mathrm{H}, \mathrm{s}, \mathrm{CH}_{3} \mathrm{CO}_{2}-26\right), 2.02\left(3 \mathrm{H}, \mathrm{s}, \mathrm{CH}_{3} \mathrm{CO}_{2}-\right.$ 3), $1.96\left(3 \mathrm{H}, \mathrm{s}, \mathrm{CH}_{3} \mathrm{CO}_{2}-16\right), 1.18\left(3 \mathrm{H}, \mathrm{s}, \mathrm{CH}_{3}-18\right), 1.10$ $\left(3 \mathrm{H}, \mathrm{d}, J_{21,20}=6.6 \mathrm{~Hz}, \mathrm{CH}_{3}-21\right), 0.92\left(3 \mathrm{H}, \mathrm{d}, J_{27,25}=6.6\right.$ $\left.\mathrm{Hz}, \mathrm{CH}_{3}-27\right), 0.92\left(3 \mathrm{H}, \mathrm{s}, \mathrm{CH}_{3}-19\right) .{ }^{13} \mathrm{C}$ NMR $(100 \mathrm{MHz}$, $\mathrm{CDCl}_{3} \delta$ ): 36.2 (C-1), 27.1 (C-2), 73.1 (C-3), 28.1 (C-4), 44.3 (C-5), 31.0 (C-6), 33.6 (C-7), 34.7 (C-8), 56.6 (C-9), 36.2 (C-10), 38.1 (C-11), 212.9 (C-12), 56.3 (C-13), 54.8 (C-14), 34.4 (C-15), 74.3 (C-16), 46.2 (C-17), 12.8 (C-18), 11.8 (C-19), 43.9 (C-20), 17.0 (C-21), 212.4 (C-22), 37.8 (C-23), 26.8 (C-24), 32.0 (C-25), 68.9 (C-26), 16.6 (C-27), 170.6 $\left(\mathrm{CH}_{3} \mathrm{CO}_{2}-3\right), 169.5\left(\mathrm{CH}_{3} \mathrm{CO}_{2}-16\right), 171.2\left(\mathrm{CH}_{3} \mathrm{CO}_{2}-\right.$ 26), $21.4\left(\mathrm{CH}_{3} \mathrm{CO}_{2}-3\right), 21.0\left(\mathrm{CH}_{3} \mathrm{CO}_{2}-16\right), 21.0\left(\mathrm{CH}_{3} \mathrm{CO}_{2}-\right.$ 26). IR $\left(\mathrm{cm}^{-1}\right): 2933(\mathrm{CH}), 1722(\mathrm{C}=\mathrm{O}$, acetate $), 1710$, and $1708\left(\mathrm{C}=\mathrm{O}\right.$, ketones). HRMS for $\mathrm{C}_{33} \mathrm{H}_{50} \mathrm{O}_{7}$ Calcd: 574.3506. Found: 574.3500.

Analytical data for compound 17. Colorless syrup; $[\alpha]_{\mathrm{D}}=$ $+37.8^{\circ}$ (c 0.73, $\left.\mathrm{CHCl}_{3}\right) .{ }^{1} \mathrm{H}$ NMR $\left(400 \mathrm{MHz}, \mathrm{CDCl}_{3} \delta\right): 5.07$ $\left(1 \mathrm{H}, \mathrm{s}_{\mathrm{br}}, \mathrm{H}-3\right), 4.97(1 \mathrm{H}, \mathrm{m}, \mathrm{H}-16), 3.90(2 \mathrm{H}, \mathrm{m}, \mathrm{H}-26), 2.94$ $\left(1 \mathrm{H}, \mathrm{dq}, J_{20,21}=7.2 \mathrm{~Hz}, J_{20,17}=4.0 \mathrm{~Hz}, \mathrm{H}-20\right), 2.67(1 \mathrm{H}$, m, 23a), 2.39 (1H, m, H-15 a), 2.31 (1H, m, H-23b), 2.05 $\left(3 \mathrm{H}, \mathrm{s}, \mathrm{CH}_{3} \mathrm{CO}_{2}-26\right), 2.05\left(3 \mathrm{H}, \mathrm{s}, \mathrm{CH}_{3} \mathrm{CO}_{2}-3\right), 2.00(3 \mathrm{H}, \mathrm{s}$, $\left.\mathrm{CH}_{3} \mathrm{CO}_{2}-16\right), 1.13\left(3 \mathrm{H}, \mathrm{d}, J_{21,20}=6.4 \mathrm{~Hz}, \mathrm{CH}_{3}-21\right), 0.97(3 \mathrm{H}$, s, $\left.\mathrm{CH}_{3}-19\right), 0.93\left(3 \mathrm{H}, \mathrm{d}, J_{27,25}=6.8 \mathrm{~Hz}, \mathrm{CH}_{3}-27\right), 0.84(3 \mathrm{H}, \mathrm{s}$, $\left.\mathrm{CH}_{3}-18\right) .{ }^{13} \mathrm{C}$ NMR (100 MHz, $\mathrm{CDCl}_{3} \delta$ ): 30.4 (C-1), 25.8 (C2), 70.4 (C-3), 30.3 (C-4), 37.0 (C-5), 26.5 (C-6), 26.1 (C-7), 34.9 (C-8), 39.6 (C-9), 34.6 (C-10), 20.6 (C-11), 39.8 (C-12), 42.1 (C-13), 53.6 (C-14), 34.7 (C-15), 75.6 (C-16), 55.1 (C17), 13.3 (C-18), 23.6 (C-19), 43.4 (C-20), 16.6 (C-21), 212.7 (C-22), 38.1 (C-23), 24.7 (C-24), 32.0 (C-25), 68.5 (C-26), 16.7 (C-27), $170.5\left(\mathrm{CH}_{3} \mathrm{CO}_{2}-3\right), 169.5\left(\mathrm{CH}_{3} \mathrm{CO}_{2}-16\right), 171.0$ $\left(\mathrm{CH}_{3} \mathrm{CO}_{2}-26\right), 20.9\left(\mathrm{CH}_{3} \mathrm{CO}_{2}-3\right), 20.8\left(\mathrm{CH}_{3} \mathrm{CO}_{2}-16\right), 21.3$ $\left(\mathrm{CH}_{3} \mathrm{CO}_{2}-26\right)$. IR $\left(\mathrm{cm}^{-1}\right): 2939(\mathrm{CH}), 1724(\mathrm{C}=\mathrm{O}$, acetate), $1708\left(\mathrm{C}=\mathrm{O}\right.$, ketone). HRMS for $\mathrm{C}_{33} \mathrm{H}_{50} \mathrm{O}_{7}$ Calcd: 560.3713 . Found: 560.3708 .

\section{Acknowledgements}

The authors gratefully thank CONACYT for the scholarship to $\mathrm{MAFH}$, and to PROQUINA for diosgenin gift.

\section{References}

1. Hostettmann, K.; Marston, A. Saponins; Cambridge University Press, New York, 1995, 76-96.

2. (a) Marker, R. E.; Rohrmann, E. J. Am. Chem. Soc. 1939, 61, 3592-3593. (b) Marker, R. E.; Krueger, J. J. Am. Chem. Soc. 1940, 62, 3349-3350. (c) Marker, R. E.; Tsukamoto, T.; Turner, D. L. J. Am. Chem. Soc. 1940, 62, 2525-2532. (d) Marker, R. E. J. Am. Chem. Soc. 1940, 62, 3350-3352.

3. (a) Djerassi, C.; Ringold, H. J.; Rosenkranz, G. J. Am. Chem. Soc. 1951, 73, 5513-5514. (b) Kongkathip, N.; Kongkathip, B.; Noimai, N. Synth. Commun. 2006, 36, 865-874.

4. Kubo, S.; Mimaki, Y.; Terao, M.; Sashida, Y.; Nikaido, T.; Ohmoto, T. Phytochemistry 1992, 31, 3969-3973.

5. (a) Leamon, C. P.; Reddy, J. A.; Vlahov, I. R.; Vetzel, M.; Parker, N.; Nicoson, J. S.; Xu, L. C.; Westrick, E. Bioconjugate Chem. 2005, 16, 803-811. (b) Gehrmann, M. L.; Fenselau, C.; Hathout, 
Y. J. Proteome Res. 2004, 3, 403-409. (c) Criado, J. J.; Fernández, E. R.; Manzano, J. L.; Alonso, A.; Barrena, S.; Medarde, M.; Pelaez, R.; Tabernero, M. D.; Orfao, A. Bioconjugate Chem. 2005, 16, 275-282. (d) Crow, D. M.; Williams, L.; Colcher, D.; Wong, J. Y. C.; Raubitschek, A.; Shively, J. E. Bioconjugate Chem. 2005, 16, 1117-1125.

6. (a) Deng, S.; Yu, B.; Lou, Y.; Hui, Y. J. Org. Chem. 1999, 64, $202-$ 208. (b) Yoichi, Y. Farumashia 2001, 37, 1044-1045. (c) Yu, W.; Jin, Z. J. Am. Chem. Soc. 2002, 124, 6576-6583. (d) Morzycki, J. W.; Wojtkielewicz, A. Carbohydr. Res. 2002, 337, 1269-1274.

7. Dewick, P. M. Medicinal Natural Products. A Biosynthetic Approach. $2^{\text {nd }}$ Ed. John Wiley \& Sons, Chichester. 2002, 237239.

8. Djerassi, C.; Halpern, O.; Pettit, G. R.; Thomas, G. H. J. Org. Chem. 1959, 24, 1-6.
9. Tian, W. S.; Guan, H. P.; Pan, X. F. Chin. J. Chem. 2003, 21, 794798.

10. (a) Sandoval-Ramírez, J.; Castro-Méndez, A.; Meza-Reyes, S.; Reyes-Vázquez, F.; Santillán, R.; Farfán, N. Tetrahedron Lett. 1999, 40, 5143-5146. (b) Sandoval-Ramírez, J.; Meza-Reyes, S.; del Rio, R. E.; Hernández-Linares, G.; Suárez-Rojas, A.; Rincón, S.; Farfán, N.; Santillán, R. L. Steroids 2003, 68, 199-204. (c) Rincón, S.; del Río, R. E.; Sandoval-Ramírez, J.; Meza-Reyes, S.; Montiel-Smith, S.; Fernández, M. A.; Farfán, N.; Santillán, R. Tetrahedron 2006, 62, 2594-2602. (d) Hernández-Linares, G.; Meza-Reyes, S.; Montiel-Smith, S.; Sandoval-Ramírez, J.; Gómez-Calvario, V.; Bernès, S. J. Mex. Chem. Soc. 2007, 51, 217-221. 